\title{
An Analysis Mathematics Learning Quality of Primary School Students Using Thematic Approach
}

\author{
Ika Prasetyani, Sumargiyani \\ Unversitas Ahmad Dahlan \\ JalanPramuka No. 42Sidikan, Umbulharjo, Yogyakarta, 55161, Indonesia \\ a)ika1708050016@webmail.uad.ac.id \\ b) sumargiyani04@yahoo.com
}

\begin{abstract}
This study aims to analyze mathematics learning qulity of primary school student using thematic approach. This research subject were primary school student one grade of SD Negeri 4 Sidorekso, Kudus. This study type was classroom action research that involve 30 of students. The method used descriptive qualitative. The data collected by diagnostic test techniques, observation and interview sheets. The analysis showed improvement of mathematics learning. It can be seen in the first cycle increase from $63 \%$ at the first meeting to $69 \%$ at the second meeting. The second cycle from $84 \%$ to $87 \%$ and the third cycle from $96 \%$ to $97 \%$. Moreover, the student achievement increased. In the first cycle, the average score was 76 and $70 \%$ for classical. In the second cycle the average was 84 and $82 \%$ for classical. In the third cycle the average was 91 and $100 \%$ for classical. The positive response from the students and teachers use thematic approach process can be seen from result of interview that thematic approach can improve the interest and motivation of the students.
\end{abstract}

Keywords: Quality of mathematics Learning, Thematic Approach, Classroom acton research,

\begin{abstract}
Abstrak. Penelitian ini bertujuan untuk menganalisis kualitas belajar matematika siswa sekolah dasar menggunakan pendekatan tematik. Penelitian dilakukan di SD Negeri 4 Sidorekso. Jenis penelitian ini adalah penelitian tindakan kelas dengan setting kelas I yang berjumlah 30 siswa. Penelitian dilakukan 3 siklus dan tuntas pada siklus III. Data dikumpulkan dengan teknik tes diagnostik, lembar observasi, serta wawancara. Analisis data yang digunakan adalah analisis deskriptif kualitatif. Hasil penelitian menunjukkan adanya peningkatan kualitas belajar matematika pada siswa kelas I dengan materi pokok bangun datar. Hal ini dapat dilihat dari peningkatan keaktifan siswa dalam proses pembelajaran, yaitu pada siklus I sebesar $63 \%$ pada pertemuan I dan $69 \%$ pada pertemuan II. Pada siklus II sebesar $84 \%$ pada pertemuan I dan $87 \%$ pada pertemuan II. Pada siklus III sebesar $96 \%$ pada pertemuan I dan $97 \%$ pada pertemuan II. Prestasi belajar siswa pada tiap siklus mengalami peningkatan, yaitu pada siklus I nilai rata-rata yang diperoleh siswa sebesar 76 dan ketuntasan klasikal sebesar 70\%. Pada siklus II rata-rata yang diperoleh siswa sebesar 84 dan ketuntasan klasikal sebesar $82 \%$. Pada siklus III rata-rata yang diperoleh siswa sebesar 91 dan ketuntasan klasikal sebesar $100 \%$. Respon yang positif dari siswa dan guru terhadap model pembelajaran tematik dilihat dari hasil wawancara bahwa pendekatan tematik dapat meningkatkan minat dan motivasi siswa.
\end{abstract}

Kata kunci:Kualitaspembelajaranmatematika, pendekatan tematik, Penelitian tindakan kelas

\section{INTRODUCTION}

Education is a conscious effort by families, communities, and governments by conseling, teaching, and training activities at school or out of school to prepare students play their role appropriately in various environments (Saputro, 2015), education is very important to maintain the existence of a country (Amini, 2017). Education is not only as an effort to provide information and skill, but includes effort to realize the need and student abilities to achieve a satisfactory personal 
and social patterns of live. Education not only to prepare for the next life, but for the lives of today's students who are progressing to the level of maturity.

Basic education is the underlying level to continue the next level, then the role of basic education is crucial in the repertoire of human education. Basic education has a strategic position in order to instill moral values to build a generation of superior, quality, tough, and have a strong character (Saputro, 2015). Based on the developmental age of Primary school student, mainly those who are in the first and second grade, the way these students think are holistic. Therefore, learning various subjects to make a more mainingful learning (Handayani, 2016).In general, the success of a learning is determined by the quality of the learning design (Nugraha, 2017).

Mathematics are basic science that has been introduced to students since early even taught by parents in the family environment. Mathematics need to be given to students starting from elemantary school to equip them with logical, analytical, systematic, critical, and creative thinking skills, as well as an ability to work together (Arif, 2016). Through mathematics learning is expected to foster the ability to develop skills and application, manipulating accurately and efficiently including usefullness and the role of mathematics ability at daily life (Maharani, 2015). Mathematics learning will be more mainingfull and appealing to students if teachers can present in the form of contextual and realistic problems and familiar issues. Therefore in mathematics learning required a method that makes mathematics a science that is liked and easily understoad (Arif, 2016), in addition a teacher must be adjust the level of students thinking development. For that teacher continue to develop creativity required to improve students ability to learn, so that students can progress toward a better self-actualization (Sabri, 2017).

Characteristic of elementary school students whose age ranges six to thirteen years is in a concrete operational phase. It was proposed by piaget that it this phase the ability and the process of thinking in operating the rules of logic still concrete. All object captured are still bound by the five senses. The learning process in concrete phase through varios stages in concrete, semi concrete, semi abstract, and the last abstract (Ferryka, 2017). So, it can be said that the thematics approach in elemantaryschoool is very appropriate (Kristiantari, 2014).Based on the characteristics of the lower class students, the appropriate learning model is thematic (Qodriyah, 2015).In general, the learning should be delivered by an integrative approach in a theme (Sulfashah, 2018).

Thematic approach is a learning design based on certain themes. Themes are used to link some subjects. Learning is based on the theme, as a binder of the relationship the material to be taught (Arnasih, 2015). The purpose of thematic learning inelemantary school is to make fun, to provide experience learning for students, memorable and meaningfull, to develop of thinking skills, to grow social skill, to foster tolerance, communication and responsiveness, to present real activities (Rohartati, 2013). Thematic is learning approach that blends the conceptual concept of a some subjects that focus on the central theme. Through thematic, student activities, student creativity, collaboration in learning, independence, self-confidence and student responsibilities can be greatly forged.Based on the 2013 curriculum, thematic learning is a conducted from one to six grade of elemantary school. There are three important things that need to be developed in curriculum 2013, include: (1) attitude, (2) skill, and (3) knowledge. The thematic learning is applied using a scientific approach that is: observing, asking, reasoning, trying, and forming (Sabri, 2017).Thematic learning is a learning system that allows students, either individually or in groups actively explore and discover concepts and scientific principles in a holistic, meaningful, and authentic(Wahyuningtyas, 2017).

Some research has been done on the implementation of thematic learning in the 2013 curriculum. The matter is motivated by the many obstacles faced by teachers in implementing the thematic learning in the upper grades of elementary school (Ammanaturrahmah, 2107). To overcome this conditions takes a creative teacher in developing the learning process (Anggoro, 2018). In addition, One way to implement character education in schools to incorporate character 
education into Integrated Science lessons, such as research that has been conducted by izzati (2013). This study aim to aims to analyze mathematics learning qulity of primary school student using thematic approach.

\section{METHOD}

The study was qualitative descriptive where the subject of research were Primary School Students grade 1 of SD Negeri 4 Sidorekso. This type of study is a classroom action research, which a reflection of learning activities in form of an act that deribelately appear and occur in a class together. The study design in consist of four stage in each cycle. These stages include: (1) planning, (2) acting, (3) observing, and (4) reflecting. The decision to stop or continue the cycle is join decision between the reseacher and teacher. The cycle stoped if them agree that mathematics learning trough thematic learning has been done, the students activeness and learning achievements increase, and learning completeness has been achived. The data was collected by: (1) diagnostic test, used to determine student achievement in solving the problem, (2) observation, to observe student activities during the learning process in each cycle, (3) interview, to know students response to thematic learning that has been implemented. We use some instruments to collect data in this research, include: (1) reseacher, (2) diagnostic test, (3) observation sheets, and (4) interview sheets. Data analysis techniques in this study, the data have been analyzed descriptively qualitative that present data in description form and discussion based on result of research. This is usefull for learning improvement plans in the next cycle. Data obtained in observation sheet about the learning process during the action took place, the answer to diagnostic test, and interview sheets to determine the response of students.

\section{RESULT AND DISCUSSION}

Based on analysis in diagnostic test, the improvement of learning achievement from cycle I, cycle II, and cycle III can be seen in table 1 :

Table 1.Improvement of learning achievement from cycle I, cycle II, and cycle III

\begin{tabular}{c|c|c|c}
\hline Evaluation result & Cycle I & Cycle II & Cycle III \\
\hline Number of complete student & 21 & 23 & 30 \\
\hline The highest score & 100 & 100 & 100 \\
\hline The lowest score & 30 & 40 & 70 \\
\hline Average & 76 & 84 & 91 \\
\hline
\end{tabular}

While the improvement of classical completeness and student activeness can be seen in the table 2:

Table 2.persentage of classical completeness and students activeness of cycle 1, cycle 2, and cycle 3

\begin{tabular}{|c|c|c|c|c|c|c|}
\hline \multirow{2}{*}{ Compound } & \multicolumn{6}{|c|}{ Cycle } \\
\hline & \multicolumn{2}{|c|}{ I } & \multicolumn{2}{|c|}{ II } & \multicolumn{2}{|c|}{ III } \\
\hline $\begin{array}{c}\text { Classical completeness } \\
\text { percentage }\end{array}$ & \multicolumn{2}{|c|}{$70 \%$} & \multicolumn{2}{|c|}{$82 \%$} & \multicolumn{2}{|c|}{$100 \%$} \\
\hline & 1st meeting & 2nd meeting & 1 st meeting & 2nd meeting & 1 st meeting & 2nd meeting \\
\hline $\begin{array}{c}\text { Student } \\
\text { Activitiesprecentage }\end{array}$ & $63 \%$ & $69 \%$ & $84 \%$ & $87 \%$ & $96 \%$ & $97 \%$ \\
\hline
\end{tabular}

The result of classroom action research consisting of cycle I, cycle II, and cycle III on mathematics learning through thematic approach showed an improvement the quality of students 
mathematics learning. This is seen from the result of student achievement that has increase, student activity from analysis on observation sheet at each meeting also increased.

Learning process in the first cycle students still need adjusment to the learning process through thematic learning. Student have not begun to actively ask and respond to teacher questions, but the course of grup discussion goes well. Based on the observation and diagnostic test, the persentage of students activity at the first meeting was $63 \%$, and the second meeting was $69 \%$, with $70 \%$ classical completeness.

In the second cycle of learning mathematics through thematic learning begun to have an increase of student learning quality. This is indicated by the liveness and enthusiasm of student at the learning process. Student activelly ask question, respond to questions from teachers, and present their ideas. Activity and student learning achievement also increased. The precentage of student activeness at the first meeting was $84 \%$ and the second meeting $87 \%$ with $82 \%$ classical completeness

In the third cycle students have been actively involved, either in asking the teacher or his friend, answer questions from the teacher, present the idea and courage students to ask more evenly. In addition, all students have complete individual and classical learning and an increase in student learning achievement of mathematics. The precentage of student activeness at the first meeting was $96 \%$ and in the second meeting $97 \%$ with $100 \%$ classical completeness.

From the table above can be seen there is an increase in the average value of students in first cycle of 76 increasedto 84 in cycle II, and 91 in cycle III (Table I). while the percentage of classical completeness from $70 \%$ in cycle I, $82 \%$ in cycle II, and increased to $100 \%$ in cycle III. In the first stage of diagnostic tests, there are still four items that have not been completed so that they are fixed in the second stage diagnostic test and on the diagnostic test II there are still three unresolved questions that are fixed in cycle III. The result of the third stage diagnostic test is that all the items have been completed. Table 3 present the percentage of complete item on each cycle.

Table 3.Percentage Completion Of Items Cycle I, cycle II, and cycle III

\begin{tabular}{c|c|c|c|c}
\hline Number & Cycle I & Cycle II & Cycle III & Information \\
\hline 1 & $90,00 \%$ & $92,86 \%$ & $93,33 \%$ & Completed in cycle I \\
\hline 2 & $86,67 \%$ & $92,86 \%$ & $86,67 \%$ & Completed in cycle I \\
\hline 3 & $86,67 \%$ & $92,86 \%$ & $90,00 \%$ & Completed in cycle I \\
\hline 4 & $66,67 \%$ & $92,86 \%$ & $100 \%$ & Completed in cycle II \\
\hline 5 & $53,33 \%$ & $53,57 \%$ & $86,67 \%$ & Completed in cycle III \\
\hline 6 & $63,33 \%$ & $89,29 \%$ & $90 \%$ & Completed in cycle II \\
\hline 7 & $86,67 \%$ & $60,71 \%$ & $96,67 \%$ & Completed in cycle III \\
\hline 8 & $56,67 \%$ & $92,86 \%$ & $90 \%$ & Completed in cycle II \\
\hline 9 & $86,67 \%$ & $92,86 \%$ & $86,67 \%$ & Completed in cycle I \\
\hline 10 & $86,67 \%$ & $78,57 \%$ & $93,33 \%$ & Completed in cycle III
\end{tabular}

Based on the above table about percentage completion of items cycle I, cycle II, and cycle III, can be presented in the picture below. 


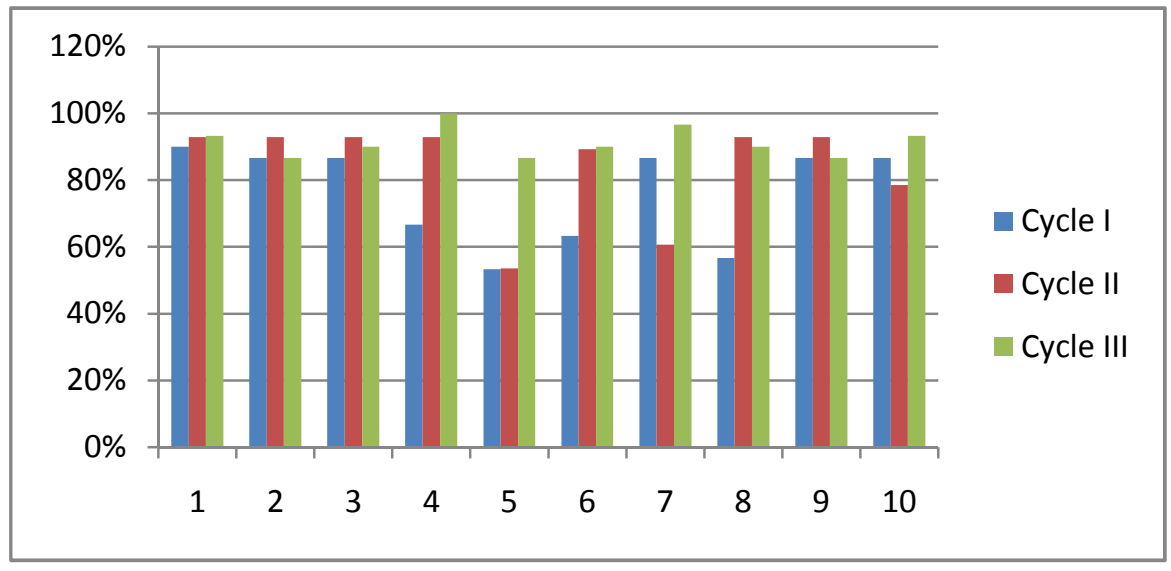

Picture 1. Percentage Completion Of Items Cycle I, cycle II, and cycle III

From the above data, the purpose of the research has ben achieved in the third cycle, so that the research is considered complete and the result of the research shous the improvement of the quality of learning mathematics. It can be seen from the improvement achievement of students and student activeness in mathematics learning through thematic approach.

Student response to mathematic learning using thematic approach is very good, from the result of interviews with student representatives. Based on the interview obtaining result :

(1) Positive responses from students and teachers to thematic approach.

(2) Thematic learning make to understand easily for student.

(3) Thematic learning can increase interest and motivation in the learning process.

(4) Mathematics learning through thematic approach can be used as reference an input.

\section{CONCLUSSION}

The research indicated several findings. First, increased student learning achievement of mathematics, from result of diagnostic test in each cycle increased, in the first cycle average value obtained by student $76 \%$ and $70 \%$ of classical completeness. In the second cycle average obtained by students of $84 \%$ and classical completeness of $82 \%$. In the third cycle average obtained by students $91 \%$ and classical completeness of $100 \%$.Second, increased activity of mathematics leraning from students use thematic approach.This is evident from the observation of student activity in the learning process, in the first cycle percentage of student activeness at the first meeting of $63 \%$ and $69 \%$ at the second meeting. In the second cycle percentage of student activeness from $84 \%$ to $87 \%$. In the third cycle percentage of student activeness from $96 \%$ to 97\%.Third, Positive responsefrom students and teacher to the thematic learning from the interviews at the end of the the third cycle meeting showed that thematic leraning approach can interest an motivation during leraning process.

\section{REFERENCE}

Amanaturrakhmah, 1.Kardoyo, Rifai, A.R..(2017). Manajemen Pembelajaran Tematik di KelasTinggi SD Percontohan Kabupaten Indramayu. Journal of Primary Education. 6(2), 159-165.

Amini, Risda.(2017). The Development of Integrated Learning Based Students'Book to Improve Elementary School Students'Competence. Unnes Science Education Journal. 6(2), 1586-1592.

Anggoro, S., Harmanto, S., Yuwono, P.D., (2018). Upaya Meningkatkan Kemampuan Pedagogik Guru Melalui Pelatihan Pembelajaran Tematik Sains Menggunakan Inquiry Learning Process dan Science Activity Based Daily Life. Jurnal Pengabdian dan Pemberdayaan Masyarakat. 2 (1), 29-35. 
Arif, M., Risnasari, M., (2016). PenerapanTeknologi Game Berhitung Untuk Meningkatkan Kemampuan Matematika pada Siswa Tingkat Sekolah Dasar. Jurnal Ilmiah Edutic. 3 (1). 48-57.

Arnasih, N.W., Marhaeni, A.A.I.N, Arnyana, I.B.P., (2015). Pengaruh Implementasi Pembelajaran Tematik Berbantuan Cerita Terhadap Aktivitas dan Prestasi Belajar calistung Siswa Kelas III SD di Gugus V Kecamatan Tegallalang Kabupaten Gianyar. JurnalPendidikanDadas Indonesia 4.1.

Basyiroh, U. (2016). Pengembangan Media Jamket (Jam Kegiatan) pada Pembelajaran Tematik Tema Kegiatanku Kelas I MI Baiturrahman Surabaya (Doktoral dissertation, University of Muhammadiyah Malang).

Ferryka, P. Z.(2017). Permainan Ular Tangga dalam Pembelajaran Matematika di Sekolah Dasar. Magista, 29 (100).

Izzati, N., Hindarto, N., Pamelasari, S.D. (2013) Pengembangan Modul Temarik dan Inovatif Berkarakter pada Tema Pencemaran Lingkungan untuk Siswa Kelas VII SMP. Jurnal Pendidikan IPA Indonesia. 2(2).183-188.

Kristiantari, M.R. (2015). Analisis Kesiapan Guru Sekolah Dasar dalam Mengimplementasikan Pembelajaran Tematik Integratif Menyongsong Kurikulum 2013. JPI (Jurnal Pendidikan Indonesia), 3 (2).

Maharani, I.N.(2015). Pengembangan Bahan Ajar untuk Meningkatkan Penguasaan Konsep Siswa Kelas II di SDN Harapan I Bandung. (Doctoral dissertation, Universitas Pendidikan Indonesia).

Nugraha, R.S.,Sumardi, S., \& Hamdu, G.(2017). Desain Pembelajaran Tematik Berbasis Outdoor Learning di SD. Indonesia Journal of Primary Education, 1(1),34-40.

Pursitasari, I.D., Nuryanti, 3. \&Rede, A. (2015). Promoting of Thematic.Based Integrated Science Learning on the Junior High School. Journal of Education and Practice, 6 (20), 97-101.

Qodriyah, S.H., \& Wangid, M.N. (2015). Pengembangan SSP Tematik Integratif untuk Membangun karakter Kejujuran dan Kepedulian Siswa SD Kelas II. Jurnal Prima Edukasia, 3(2), 177-189.

Sabri, T.(2017). Value Based Thematics Learning. JETL (Journal of Education, Teaching and Learning), 2(2), 192-196.

Sabri, T.(2017). Practical Ways Internalization Thematik by Students in Learning Through Peer Teaching in PGSD FKIP at Tanjungpura University. Journal of Education, Teaching and Learning, 2(1), 138 - 142.

Saputro, H.B., \& Soeharto, S. (2015). Pengembangan Media Komik Berbasis Pendidikan Karakter pada Pembelajaran Ttematik-Integratif Kelas IV SD. Jurnal Prima Edukasia, 3(1), 61-72.

Sulfashah, S., BAhri, A., danSaleh, S.F.(2018). Writing Lessons in Grade I Indonesian Thematic Text book: A content Analysis. Indonesian Journal of Applied Linguistics, 7(3), 495 - 503.

Wahyuningtyas, D.T., danSuastika, I.K.,(2017). Developing of Numbers Learning Module for Primary School Students by Contextual Teaching and Learning Approach. JPDI (Jurnal Pendidikan Dasar Indonesia), 1(2), 33 - 36.

Yuliyanti, E. (2016). Pengembangan Pengelolaan Pembelajaran Tematik Berbasis Permainan Injak Kartu Angka pada Kelas I SD Negeri 2 Pulongrambe Kecamatan Tawangharjo Kabupaten Grobogan (Doctoral dissertation, Universitas Muhammadiyah Surakarta). 